\title{
Expository Analysis of Economic Base in a Consumerist World
}

\author{
Bakare Ayoola Najimdeen \\ Department of International Relation \\ Preston University, $\mathrm{H}-8$, Street 3, Islamabad, Pakistan \\ Email olaaayo@gmail.com \\ Amna Tauhidi \\ Department of International Relation \\ National Defense University Islamabad, Pakistan \\ amnatauhidi01@hotmail.com
}

Doi:10.5901/mjss.2014.v5n1p219

\begin{abstract}
The economic base is one of Marx's grand and indelible thoughts. According to Marx the modern capitalist society is a reflection of the economic base. Although the whole idea of the economic base presents a materialist understanding of history, yet the unfolding realities reveal that the base remains powerful as Marx predicted. The paper revisits Marx's view of historical act and its ramifications on the intellectual base and epistemic community in particular and the larger society in general. The paper further raises the questions, should academic institutions dance to the tune of the economic base and should the intelligentsia and the epistemic community bow to the dictation of the economic base? How much should we allow the economic base to shape our consciousness and thinking process? Could there be an alternative to the dictate of the economic base? And finally, does inaction and lack of vigour to effect change give the base an undisputable challenge and thereby leading to class division and class conflict.
\end{abstract}

Keywords: Economic Base, Historical Act, Consumerism, Property, Market, Globalisation

\section{Introduction}

The German born philosopher, Karl Marx became an intellectual celebrity on account of his grand and indelible thoughts, upon which a distinction between the utopian and scientific socialism was drawn. Marx scientific and argumentative narrative of the economic base presents a materialist understanding of history and reflected the swaying hold of the base to the extent of molding consciousness at all levels of the society. The $20^{\text {th }}$ century analysis of Marx remains alive and we shall be presenting how forceful the economic base remains as powerful and enthralling structure. Graphic representation of the economic base will undoubtedly be incomplete without a corresponding analysis of other ideas of Marx that elucidate the ramifications of the base.

The birth and celebrated philosophy of Marxism was a watershed in modern philosophical thought; although (Brian, 1996) suggests Marxism was an anti-political theory, given its brilliance and alternative narrative. The celebration and fame of Marxism in modern history revolves around scientific socialism, a dividing and distinctive polemic against the idealism of the Utopian Socialist (Brian, 1996).

Within the Marxist narrative, the Utopian socialists were beclouded by abstraction, buried in the realm of idealism and metaphysic, and therefore deprived of making an intuitive argument on the materialistic concept of history and society. If survival is essential to all living species, mostly human, thus Marx argues such survivalist propensity will make no headway not until the first historical act is made. "The first historical act is thus the production of the means to satisfy these needs, the production of material life itself," (Elster, 1986:174).

Marxist polemic further weaved up a connection between history and survival "The first premise of all human existence and, therefore, of all history, the premise, namely that men must be in a position to live in order to be able to "make history." (Marx and Engel, 2008:48)

The mode and means of production shapes what will be of a society, and hence of an economy. Marx argues that economy never changes; rather it is the functional technology that succumbs to changes and that ultimately brings about a change in the mode and mean of production, which invariably changes the whole society. Marx sees economic 
exploitation, division of labour and class division as corresponding to a particular level of technology development, which could be biological, natural and spontaneous. (Palumbo and Scott, 2005)

Enunciating the implication of class and labour division, Marx argues that such corresponding relations constitute the economic base of society and invariably the latter becomes the foundational base for legal, political, ideological and intellectual superstructures, a transformation of the latter is dependent on any form of change at the economic base. (Keat and Urry, 1974:74) The economic differentiation paves way for class domination, (the dominant economic class) controlling the economic base. Marxist polemic weighs class division as the extent to which an individual is accessible to economic clout and therefore the determinant of class consciousness (Appelrouth and Edles, 2008:402).

Division of labour became the factor for social life and social order. This occurs as a result of differentiation between material and mental labour. Marx further argues that property ownership is an indication of what kind of labour a person can sell. In Marx's view this becomes the order for exploitation and structure of class exploitation, from division of activities to division of property. Division of labour and private properties are identical, as certain productive tasks are rewarded more than others, both in terms of quantity and quality, thereby paving way for social stratification (Wendy Bottero, 2005:34).

\section{Corollary of the Economic Base}

\subsection{Property}

Property lies as the underlying premise of Marx's argument. Meanwhile, class division is connected with division of labour and the latter is a representation of the nature of property that one can hold custody of. Human nature and aggrandisement lent Marx and his compatriots the opportunity to see history from the lens of materialism. Such disposition insinuates a failure of being enlightened by the classical thought of Locke, "as much as anyone can make use of to any advantage of life before it spoils, so much by his labour he may fix a property in; whatever is beyond this, is more than his share, and belongs to others" (Morgan, 2005). In this backdrop, Locke can be identified with non-wastage economy, instead of entertaining spoil and aggrandisement, redistribution of wealth and resource should be the rational step and action, potential enough to mitigate against class struggle and conflict. Locke's view on property presents a cushion of comfort for Marx's polemic on division of labour, which he claims brews inequality. Arguably, from Locke's prism of economic base, the introduction of monetary system highlights economic inequality and thus class division (Tully, 1980).

Categorically, Marx might not have mentioned the implication of historical act, but argumentatively, the making of historical act is in-divorceable from class competition and thus class division. The latter is symbolism and representation of resource accessibility and affordability. In a precarious situation, personified by the paucity of resources, (such as the case of electricity load shedding in Nigeria, Pakistan and many developing nations) the utility of the scarce resource creates a jeopardy and marginalization. Following the maximization of resources by the privileged at the detriment of the less-privileged, who lacks the propensity to compete adequately with the privileged, the system creates a "celebrity scenario" in turn lending more prerogatives to the latter over the former.

This is true for a contextual understanding of the core and periphery (David Held et al., 1983). Revisiting Lenin's argument of imperialism as the highest form of capitalism (Jones, 2005) raises the question on the identical correlation between colonialism and the economic base structure and the extent to which exploitation of resources and class division within the core, periphery and between the two accentuated.

\subsection{Intellectual Base}

The stance of Marx was crystal clear on whoever controls the economic base of the society, will obviously control the political, intellectual and social bearing of the society. This is more than a reality as the economic base of our society becomes the determinant of what to teach and learn in academic institutions. Such a scenario underpins Antonio Gramsci's discourse of dominant ideology, as the latter uses its influence of cooption and such academic institutions as mechanism to reproduce itself (Kumar, 2003).

The making of the intellectual establishment is increasingly associated consciously or otherwise with the necessity and dictate of the economic base. Epistemic communities have always been an integral and instrumental in effecting social change, though only when these opinion makers (scholars) operate within a transparent and independent vicinity. As the economic base gets stronger and with the tendency of incorporating the epistemic communities, the capacity of 
the latter community to effecting change on societal ills loses potent (Rayner, et al, 2004:285).

The sedimentation of the society on account of the hegemonic position of the economic base creates an unquestioned commonsense (Baylis and Smith, 2001:210). It thus follows that the academic institutions becomes the grounding mechanism by which the economic base gets strengthened, complemented and affirmed. Premised on this template, Pierre Bourdieu argues that the academic institution becomes a front of the powerbase of the society (Hardin, 2001).

\subsection{Household}

The sway of the economic base transcends the intellectual base, and even has its tentacles reaching the household. The competitive display of the household alongside people, class and state as noted by Immanuel Wallerstein (Taylor and Flint, 2001) enhances our understanding on two levels. One, that the household competition is a salient feature of capitalist urban settlement (Cochrane, 2003). Two, the economic base does not exculpate the household from its grasp.

The incapacity of the household to escape the influence of the economic base provides the premise for a logical argument. In today's world characterised as a knowledge-based economy underpins the growing demand of career, which invariably means scrambling for higher education irrespective of the cost. The market demand of the economic base coerces the household in making decisions that are independently theirs.

The possession of a paper certificate is increasingly turning into fashion (historical act) and means by which needs can be satisfied. Such historical act plunges families into the hard task of making end meet and the underprivileged turn out hopeless and socially dislocated. Hence, making real historical act and fulfilling careers becomes the prerogative of a few. The risk of the socially dislocated accentuates as making a career would mean running after debt. Borrowing from the simple corn model, an extra corn possessor stays on top of the ladder on account of having greater opportunity in comparison to a single corn owner less immune to the credit and capital market (Hahnel, 2007).

In a country like Pakistan with a divided education system and where paper certificates is premium, the economic base and the sense of making the historical act is forcing an appreciable number to seek university education, even though these seekers either lack the aptitude or instrument of tackling the rigour of higher education. The deductive submission of this scenario further enhances our understanding, why the proliferation of private higher institutions is taking root and growingly becoming money-making machines. The proliferation underlines Marxist argument of the economic relations between the capitalists and the labourers. This is also true for the desperate certificate seekers and money-making institutions always ready to award degrees in as much as the seeker can pay.

Prior to its nascent democratic dispensation, Nigeria was not merely plagued by the authoritarian rule of the military junta; the disease accompanied by military rule became endemic and entrenched in the psychic of many Nigerians. The protracted military rule in the country had a deep impression on the whole populace, an epoch when the "khaki boys" simultaneously controlled the economic bases. On account of the hegemonic position of the military establishment, most Nigerian parents turned towards the barracks, not just as the powerhouse, but wanting and choosing a military career for their wards. Undoubtedly, the authoritative green "khaki" was a surety of commanding societal respect and being part of power corridor. The military epoch recorded a high enthusiasm and enrolment into military schools, right from the primary, all through the elitist Nigerian Military School (secondary education) and Nigerian Defense Academy (tertiary education).

\subsection{Global Consumerism}

Globalisation has credited itself as a vehicle for the mobility of professionals, experts, capital and resources beyond borders (Stiglitz, 2006). The growing role of MNC's and their capacity as movers of capital, experts and technology have become one of the paramount driving forces for the selection of discipline in tertiary institutions. The enthusiastic trend for MBA and IT certification and degrees is inexplicable outside the boundary of global consumerism and business. The choice of MBA and IT became a spate, not because they are easy subjects to go by, rather the economic benefit and chances of controlling the market makes them highly sought after (Carter, 1998:193). If modern economic globalization is dominated by MNC and tagged as knowledge-based economy, then random choice of academic discipline will make no meaning, save treading the path set forth by the economic base. The trend is not implausible as the outsourcing movement gains footing across borders, the jobs traditionally handled by Americans and Europeans are now eroding into the hands of skilled workers from the global south (Stiglitz, 2006). The claim that the globalization champions a knowledge based economy has become a repeated mantra, though it is not inconceivable that the economic base 
decides the nature of the knowledge.

It would demand little or no advance logic to understand how educational achievement is progressively becoming an integral part of consumerism. The choice of institutions and academic discipline bears no difference from the selection made by a consumer on the type and kind of product to procure in the market. Education is more or less a brand as any other appealing product. On the prescription of the economic base, which dictates the choice of academic discipline, prospective students do not jump into any field but that which is more marketable and embedded with out-of-school benefits. The plausibility and feasibility of making a niche within the economic base is thus measured by the profitability of that particular academic discipline. Consumers struggle for quality and affordable products, and the same is true for (academic) producers seeking the best of minds to enhance their economic standing. The delineation is the strengthening of the economic base.

The overarching implication is the transformation of education into a commodity that can be sold or outsourced, instead of knowledge being a torchlight of progress and enlightenment; it has rather become a marketable commodity, where the invisible hand of demand and supply determines its bearing.

Hegemonic consolidation of the economic base affords it more leverage and enchantment proclivity. Consumerism of education is further underscored by placing academic institutions and the knowledge they offer on the scale of ISO. The scaling system offers explanation for differentiation, competition and productive efficiency of the institutions (Olivares and Wetzel, 2011). These parameters help to further underpin the institutionalization of division in academic institutions and hence academic class consciousness. Therefore, inability to attain the ISO certification or the inaffordability of the ISO certified institutions create disenfranchisement.

In the world of consumerism and capitalist competitive environment, the likelihood of frustrated buyers and sellers is not a distant reality (Hahnel, 2007). One cannot think less for the visibility of frustrated students and institutions lacking the ability and potential to compete, just as certain buyers go to the market but lack the purchasing power to purchase, or are unable to match up with the market price. This is also true for certain sellers, getting frustrated as their products get rejected in the market, either for lacking the latest technology or being sidelined by the monopolistic tendency of other competitors. We can also apply this formula to students and institutions. This analogy reminds us of the prophetic proposition of Marx that capitalism contains the seed of its own destruction (Farmer, 2006), its destruction will come forth through same factors responsible for its growth. Arguably the relevance and irrelevance of companies and industries is determined by accessibility to the latest technology, technical know-how, and competitive structures. Consumerism can do the same for academic institutions.

The trend of consumerism is playing significant role in the bifurcation and disparity in our education system and the frustration drift is ever more prevailing in terms of frustrated schools and students studying and graduating from the traditional schooling system or from the non-English medium schools. The slim opportunity created by the system exacerbates the frustration manifold. At the end of the aisle lies the English medium schooling (O/A level) system, facilitated by the economic base, championed and protected by the elite. The disparity in the schooling system bears the insignia of class division and an avenue by which the ruling class protects, maintains, reproduces and stabilises the hegemonic tendency of the economic base.

\section{Conclusion}

The global economy has seen a wonderful boom but nevertheless unable to shield itself from woes and afflictions of the same factors responsible for its growth. The recent global financial crises (American and Eurozone) reiterate and underpin the debate that capitalism possesses an inbuilt destructive system. Such an argument might though stand in contradiction to the end of history theory (Fukuyama, 1991) hence; imperatively capitalism needs the process of humanization (Hahnel, 2007).

The American financial crisis threw the rest of the world into the ring of uncertainty given the huge investments of countries in the American economy. Amidst the grappling on the extent to which the Breton Wood system has caused the entire global financial system and need for recovery, the Eurozone crisis that followed further exacerbates the tension. Financial irresponsibility and dearth of structural regulatory mechanism were identical with the financial crises at both ends of the Atlantic. The crises casted a serious doubt on the analysis of the end of history (Fukuyama, 1991) and underlines Marx argument that capitalism is structurally sculpt for its own destruction (Heaven and BBC, 2011). The implication of this was a reminder of the Limit to Growth thesis (Elkins, 2000), which challenged the economic base geared at unlimited development.

An economic base tailored towards unlimited growth has played a significant part in the degradation of the only 
and yet provable home of mankind. Recently, we have seen the outlandish effect of climate change and global warming. Meanwhile, number of environmental conferences and summits held to streamline things have lacked fruition, giving the resistance and unbending position of regions and countries controlling the economic base, thereby the Copenhagen climate summit was "weak agreement designed to mask the political failure of the international community to create a global climate treaty," (Dimitrov, 2010). The Rio 20+ Earth Summit (2012) replayed the mantra of failure witnessed in all UN climate change summits (Copenhagen in 2009, Cancun in 2010 and Durbin in 2011), (Cohen, 2012).

The global economic base forced China out of its shell of isolation to becoming an integral part of the liberal capitalist system at the financial and economic realm. From 1945 till the mid-1970s, Chinese policy makers were grappling on how to acculturate itself with the increasingly global economic and financial system. Chairman Deng Xiaoping, whose westernised reforms brought China to the shore of development, acknowledged adopting westernised "advance experience and technology as well as utilising funds from developed countries...," as the mechanism to move China out of isolation. Xiaoping's realisation was the need to give China a niche in the economic base of globalization, thus the 'two-perspective of opening up policy' (Dan, 2009). The growth of the Chinese export economy demands no introduction, China indeed has joined the bandwagon of enormous exploiters of global resources and thereby occupying an undisputable rank as the world's foremost polluter (Goldenberg, 2012).

Mushrooming of academic institutions on the enchantment of the economic base proves the self-interested syndrome of these institutions (Heilbroner, 1992: 55) like potential frustrated sellers, sizeable amount of these institutions fail to past the post (for accreditation) and concurrently plenty of the frustrated certificate seekers lacking the resources to enroll in the well-established institutions.

One overarching ramification of the economic base in terms of determining the academic discipline is the divide and competition between the private and public academic sectors, both competing for degree and certificate seekers, the way capitalist scrambles over labour. The pseudo consciousness by which the government lives with, sabotages any effort to upgrade the public school and deprives it the competitive edge to challenge the private institutions that have more or less become the repository of apparatuses useful for the reproduction and consolidation of the economic base.

The yield of education is always futuristic and the demand of the current global economic base is a knowledgemarket base. In such an environment a bifurcated educational system and structure will have little or no significance and thus less enterprising. Disengaging the current scenario and disenfranchisement from the economic base will be logically fallacious. Redressing the disparity, restructuring and harmonizing the incongruity system are overdue. This will be true and essential for most countries in the global south to match towards a harmonious and common educational goal is a conceivable option.

Marx offered a more scientific explanation before the polemic against utopian socialist could be valid. A harmonious and common educational goal will be the scientific remedy and swabbing process to removing the Pareto Inefficiency, the incongruent educational system has caused many developing economies. The enchantment of economic base is so potent, creating a strong consciousness that beclouds the government from either challenging the outlandish privatization of the academic institutions or furnishing the existing public schools to be more competitive. Bringing up reconciliatory policy at both private and public level geared at bridging an understanding between the industries and academic institutions will be instrumental in the humanisation of the economic base. The humanisation process serves an economy well as it drives the economy towards bolstering the capability and potential of GDP (Hahnel, 2007).

The Pareto inefficiency has created both conscious and unconscious socio-political dynamics, coupled with the disparity in educational institutions. The role of economic dislocation as an integral determinant of extremism cannot be underestimated. Extremism and terrorism are merely not borne out of enemy-image or hatred for other but has to do with the corollary of the socio-economic injustice in the society. The latter cannot be disconnected from the economic base. The dislocation is heightened in the developing world witnessing more of frustration and ire, which is sometimes shaped by disparity of educational opportunity and accessibility to jobs.

The ground reality shows the efficacy of the economic base and making any sort of historical act will be unrealistic without dancing to the tune of the base. The challenging task to modern thinkers is how to create a socio-economic balance; this task has never been that easy to achieve giving the pace by which technology moves. To stop the economic base from further widening and deepening class division and hence class conflict might be a farfetched ambition, yet the tempo of the anger can be mellowed down upon a humanisation of the system. 


\section{References}

Appelrouth, S. and Laura, E. (2008). Classical and Contemporary Sociological Theory: Text and Readings. London: Sage Publication. Baylis, J. and Steve, S. (2001). The Globalization of World Politics. Karachi: Oxford University Press.

BBC, (2011,September). A Point of View: The revolution of capitalism. http://www.bbc.co.uk/news/magazine-14764357 (Accessed August 9,2012 )

Bottero, W. (2005). Stratification: Social Division and Inequality. New York: Routledge.

Brian, N. (1996). Western Political Thought from Socrates to the Age of Ideology. Englewood Cliffs: Prentice-Hall.

Carter, D. (1998). MBA: The First Century. Cranbury, New Jersey: Associated University Press.

Cochrane, A. (2003). Cities. In P. Daniels (ed.), Human Geography: Issues for the 21st Century (pp. 105-127). New Delhi: Pearson Education.

Cohen, T. (2012, June). The Rio 20+ Earth Summit: Sustaining a Sustainable Dialogue. (Online). Fairobserver. http://www.fairobserver.com/node/32064

Dan, Li. (2009). From "Opening up to the world" to "Building a Harmonious World." Peace, Serial No. 90, 2-4.

Dimitrov, R.S. (2010) Inside UN Climate Change Negotiations: The Copenhagen Conference, (Online). Review of Policy Research, 1 http://politicalscience.uwo.ca/faculty/dimitrov/climate\%20negotiations\%20RPR.pdf (Accessed August 9, 2012)

Elster, J. (1986). Karl Marx: A Reader. New York: Cambridge University Press.

Elkins. P. (2000). Economic Growth, Human Welfare and Environmental Sustainability. London: Routledge

Farmer, B. (2006). American Political Ideologies: An Introduction to the Major Systems of Thought in 21th Century. North Carolina: Mcfarland and Company Inc Publishers.

Fukuyama, F. (1991). The End of History and the Last Man. New York: Macmillan.

Goldenberg, S. (2012, July). UK ranked most energy efficient of world's largest economies. (Online). Guardian, http://www.guardian.co.uk/environment/2012/jul/12/uk-ranked-most-energy-efficient (Accessed August 9, 2012)

Hahnel, R. (2007). The ABCs of Political Economy: A Modern Approach. New Delhi: Viva Books Private Limited.

Hardin, J. (2001). Opening Spaces: Critical Pedagogy and Resistance Theory in Composition. Albany, New York: State of University of New York Press.

Heaven, P. (2011, August). Marx was Right; Capitalism can Destroy itself: Roubini. (Online). Financial Post. http://business.financialpost.com/2011/08/12/roubini-says-more-than-50-chance-of-global-recession/ (Accessed August 9, 2012)

Held, D., et al., (1983). States and Societies. New York: New York University Press.

Heilbroner, R. (1992). The Worldly Philosophers: The Lives, Times, and Ideas of the Great Economic Thinkers. California: Simon and Schuster

Jones Brian (2005). Imperialism the Highest Stage of Capitalism. (Online). International Socialist Review. Issue 44. http://www.isreview.org/issues/44/imperialism.shtml

Keat, R. and John, U. (1974). Social Theory as Science. London: Routledge.

Kumar, K. (2003). Ideology and Political System. New Delhi: Discovery Publishing House.

Marx, K. Friedrich, E. (2004). The German Ideology. C.J Arthur (ed.), New York: International Publishers.

Morgan, M. (2005). Classics of Moral and Political Theory. Indianapolis: Hackett Publishing Company.

Olivares, M. and Heike, W. (2011). Competing in the Higher Education Market: Empirical Evidence for Economies of Scale and Scope in German Higher Education Institutions. Working Paper Series in Economics, 223, University of Luneburg, Institute of Economics.

Palumbo, A. and Alan, S. (2005). Marx and Durkheim. In A. Harrington (ed.), Modern Social Theory. (pp. 40-62). Oxford: Oxford University Press.

Rayner, P. Peter, W. and Stephen, K. (2004). Media Studies: The Essential Resource. London: Routledge.

Taylor, P. and Colin, F. (2000). Political Geography: World Economy, Nation-state and Locality. New Delhi: Pearson Education.

Tully, J. (1980). A Discourse on Property. Cambridge: Cambridge University Press.

Stiglitz, J. (2006). Making Globalization Work. London: Allen Lane. 